\title{
Pengaruh Asimetri Informasi dan Ukuran Perusahaan terhadap Manajemen Laba pada Sub Sektor Industri Rokok yang Terdaftar di Bursa Efek Indonesia Periode 2013-2017
}

\author{
Esty Rohayati \\ Mahasiswa Fakultas Ekonomi Prodi Manajemen Keuangan Universitas Batanghari Jambi \\ Corresponding email: esty733@gmail.com
}

\begin{abstract}
Earnings management as a phenomenon is influenced by various kinds of factors that are the drivers of the emergence of this phenomenon. Information asymmetry and firm size are believed to influence earnings management. Several studies on the effect of information asymmetry and firm size on earnings management have been carried out. However, the results obtained still show inconsistencies, especially the size of the company. In this study, earnings management was measured by The modified Jones Model to calculate discretionary accruals. Information asymmetry is measured using bid-ask and the size of the company is measured using total assets. The study population consisted of 4 companies and the observation period starting in 2013-2017. The data used in this study are secondary data and sample selection using the purposive sampling method. Based on the results of the purposive sampling obtained 4 companies in the cigarette sector that met the sample criteria. The analytical method used is a multiple linear analysis method to test the effect of information asymmetry and firm size on earnings management. Statistical analysis is used, namely 1. Testing classic assumptions, which consist of normality test, heterocedasticity test, multicollinearity test and autocorrelation test. 2. Testing the hypothesis, which consists of a test of the coefficient of determination $\left(R^{2}\right)$, partial hypothesis testing (t-test) and simultaneous hypothesis testing (F-test). Based on the results of hypothesis testing using multiple linear analysis in this research, it can be concluded partially that information asymmetry has a positive and significant effect on earnings management, while firm size has a positive and significant effect on earnings management. As well as simultaneous testing, it was concluded that information asymmetry and company size had a positive and significant effect on earnings management in 4 (four) companies, Cigarette Industry Sub-Sector Registered on the Indonesia Stock Exchange (IDX). From the results of testing the coefficient of determination or ( $R$ Square) from the results of the second regression the independent variable (Information Asymmetry and Company Size) on Earnings Management is 99.0\%, so based on the research results $99.0 \%$ (10099.0) and the rest 1,0\% is influenced by other factors not examined in the study.
\end{abstract}

Keyword: Information Asymmetry, Company Size and Profit Management

\section{PENDAHULUAN}

Asimetri informasi merupakan suatu keadaan dimana manajer memiliki akses informasi yang lebih banyak mengenai prospek perusahaan yang tidak dimiliki oleh pihak eksternal perusahaan. Keberadaaan asimetri informasi dianggap sebagai penyebab manajemen laba. Richardson (1998) berpendapat bahwa terhadap hubungan yang sistematis antara asimetri informasi dengan tingkat manajemen laba. Adanya asimetri informasi akan mendorong manajer untuk menyajikan informasi yang tidak sebenarnya terutama jika informasi itu berkaitan dengan pengukuran kinerja manajer. Kualitas laporan keuangan juga akan mencerminkan tingkat manajemen laba.

Selain asimetri informasi, faktor lain yang mempengaruhi praktik manajemen laba yaitu ukuran perusahaan. Ukuran perusahaan merupakan nilai yang menunjukkan besar kecilnya perusahaan. Terdapat dua pandangan tentang bentuk hubungan ukuran perusahaan dan manajemen laba. Pandangan pertama menyatakan ukuran perusahaan memiliki hubungan positif dengan manajemen laba, karena perusahaan besar memiliki aktivitas operasional yang lebih kompleks dibandingkan perusahaan kecil, sehingga lebih memungkinkan untuk melakukan manajemen laba. Pandangan kedua menyatakan ukuran perusahaan memiliki hubungan yang negatif dengan manajemen laba.

Ukuran perusahaan merupakan nilai yang menunjukan besar kecilnya perusahaan. Perusahaan besar akan lebih diperhatikan oleh pihak luar dibandingkan perusahaan-perusahaan yang lebih kecil. Para manajer yang mengelola perusahaan besar tidak termotivasi untuk melakukan rekayasa dalam laporan keuangannya dan memilih untuk mengutamakan kepentingan pemegang saham, sedangkan perusahaan kecil lebih leluasa untuk mengubah laporan keuangannya karena kurangnya perhatian dari pihak luar (Sulistyanto, 2008: 208).

Berikut dapat digambarkan perkembangan asimetri informasi, ukuran perusahaan dan manajemen laba perusahaan sub sektor industri rokok yang terdaftar di BEI periode 2013-2017:

Tabel 1. Asimetri Informasi Pada Sub Sektor Industri Rokok Yang Terdafatr di BEI Periode 2013-2017

\begin{tabular}{cccccc}
\hline \multirow{2}{*}{ Kode Saham } & \multicolumn{5}{c}{ Asimetri Informasi (\%) } \\
& 2013 & 2014 & 2015 & 2016 & 2017 \\
\hline GGRM & 0,0259 & 0,0419 & 0,0392 & 0,0321 & 0,0472 \\
HMSP & 0,0032 & 0,0329 & 0,0643 & 0,0636 & 0,0530 \\
RMBA & - & - & - & - & 0,0513 \\
\hline
\end{tabular}


Esty Rohayati, Pengaruh Asimetri Informasi dan Ukuran Perusahaan terhadap Manajemen Laba pada Sub Sektor Industri Rokok yang Terdaftar di Bursa Efek Indonesia Periode 2013-2017

\begin{tabular}{cccccc}
\hline WIIM & 0,0857 & 0,0611 & 0,1140 & 0,0351 & 0,1646 \\
Jumlah & 0,1148 & 0,1360 & 0,2439 & 0,1307 & 0,3160 \\
Rata-rata & 0,023 & 0,027 & 0,049 & 0,026 & 0,063 \\
Perkembangan & - & 18,46 & 79,38 & $(46,39)$ & 141,68 \\
\hline
\end{tabular}

Sumber: Data diolah

Dari tabel 1 dapat diketahui bahwa diketahui asimteri informasi perusahaan terus mengalami fluktuasi dari tahun 2013-2017 dengan jumlah sebsar 0,1148 dan 0,1360 pada tahun 2013-2014 atau dengan rata-rata perkembangan pada tahun 2013-2014 sebesar 18,46\%. Pada tahun 2015 dengan jumlah 0,2439 atau dengan peningkatan rata-rata perkembangan pada tahun 2015 sebesar 79,38\%. Pada tahun 2016 jumlah asimetri informasi sebesar 0,1307 atau dengan penurunan ratarata perkembangan pada tahun 2016 sebesar (46,39\%). Pada tahun 2017 jumlah asimetri informasi sebesar 0,3160 atau dengan peningkatan kembali dengan ratarata perkembangan pada tahun 2017 sebesar 141,68\%.

Selain asimetri informasi, faktor lain yang berhubungan dengan praktik manajemen laba adalah ukuran perusahaan. Ukuran perusahaan merupakan nilai yang menunjukkan besar kecilnya perusahaan. Investor dalam menanamkan modalnya biasanya akan memilih perusahaan yang mampu menunjukkan kinerja yang baik agar modal yang ditanamkan nantinya memperoleh hasil yang menguntungkan. Hal tersebut bisa dibedakan dari ukuran perusahaan. Ukuran perusahaan berpengaruh negatif terhadap manajemen laba. Perusahaan dengan ukuran besar biasanya akan lebih berhati-hati dalam menyusun dan melaporkan hasil kinerjanya berupa laporan keuangan yang akan diterbitkan. Berikut adalah gambaran ukuran perusahaan sub sektor industri rokok yang terdaftar di BEI periode 2013-2017:
Tabel 2. Ukuran Perusahaan Pada Sub Sektor Industri Rokok Yang Terdafatr di BEI Periode 2013-2017

\begin{tabular}{cccccc}
\hline & \multicolumn{5}{c}{ Ukuran Perusahaan $(\%)$} \\
Perusahaan & 2013 & 2014 & 2015 & 2016 & 2017 \\
\hline GGRM & 17,74 & 17,88 & 17,97 & 17,96 & 18,02 \\
HMSP & 17,13 & 17,16 & 17,45 & 17,57 & 17,58 \\
RMBA & 16,04 & 16,20 & 16,35 & 16,42 & 16,46 \\
WIIM & 14,02 & 14,10 & 14,11 & 14,12 & 14,02 \\
Jumlah & 64,93 & 65,34 & 65,88 & 66,06 & 66,08 \\
Rata-rata & 16,23 & 16,34 & 16,47 & 16,51 & 16,52 \\
Perkembangan & - & 0,64 & 0,83 & 0,26 & 0,03 \\
\hline Sunnnyyynn
\end{tabular}

Sumber : Data diolah

Dari tabel 2 dapat diketahui bahwa ukuran perusahaan mengalami peningkatan dari tahun 20132017, ini dapat dilihat dari jumlah ukuran perusahaan pada sub sektor industri rokok yang terdafatr di BEI periode 2013-2017 dengan jumlah 64,93\% dan 65,34\% pada tahun 2013-2014 dengan perkembangan sebesar 0,64\%. Pada tahun 2015 jumlah ukuran perusahaan sebesar $65,88 \%$ atau dengan perkembangan sebesar $0,83 \%$. Pada tahun 2016 jumlah ukuran perusahaan sebesar $66,06 \%$ atau dengan perkembangan sebesar 0,26\%. Pada tahun 2017 ukuran perusahaan mengalami penuruan sebesar $66,08 \%$ dari tahun sebelumnya atau dengan perkembangan sebesar $0,03 \%$.

Sampai saat ini manajemen laba area yang paling kontroversial dan penting dalam akuntansi keuangan. Manajemen laba tidak selalu diartikan sebagai suatu upaya negatif yang merugikan, karena tidak selamanya manajemen laba berorientasi pada manipulasi laba. Dalam praktik manajemen laba, manajer berkewajiban untuk menyampaikan kondisi perusahaan kepada pemegang saham terkadang tidak menyampaikan informasi yang sesuai dengan kondisi perusahaan sebenarnya. Kondisi ini sering disebut sebagai informasi yang tidak simetris atau asimetri informasi (information asymmetric). Berikut adalah gambaran manajemen laba perusahaan sub sektor industri rokok yang terdaftar di BEI periode 2013-2017:

Tabel 3. Manajemen Laba Pada Sub Sektor Industri Rokok Yang Terdafatr di BEI Periode 2013-2017 Manajemen Laba (\%)

\begin{tabular}{|c|c|c|c|c|c|}
\hline \multirow[t]{2}{*}{ Kode Saham } & \multicolumn{5}{|c|}{ Tahun } \\
\hline & 2013 & 2014 & 2015 & 2016 & 2017 \\
\hline GGRM & $(1,3179)$ & $(1,3549)$ & $(1,3304)$ & $(1,5083)$ & $(1,5419)$ \\
\hline HMSP & $(2,8560)$ & $(2,9286)$ & $(1,5632)$ & $(2,3236)$ & $(2,4317)$ \\
\hline RMBA & $(1,5723)$ & 1,6190 & $(1,6658)$ & $(1,6328)$ & $(1,7009)$ \\
\hline WIIM & $(93.567,1055)$ & $(163.415,5740)$ & $(185.764,5083)$ & $(298.793,5177)$ & $(368.085,6838)$ \\
\hline Jumlah & $-93572,8517$ & $-163418,2385$ & $-185769,0677$ & $-298798,982$ & $-368091,3583$ \\
\hline Rata-rata & $-23393,2129$ & $-40854,55963$ & $-46442,26693$ & $-74699,7456$ & $-92022,83958$ \\
\hline Perkembangan & - & 74,64 & 13,68 & 60,84 & 23,19 \\
\hline
\end{tabular}

Sumber: Data diolah

Dari tabel 3 dapat diketahui bahwa manajemen laba pada sub sektor industri rokok yang terdaftar di BEI periode 2013-2017 pada perusahaan Gudang Garam dengan nilai tertinggi pada tahun 2017 sebesar $(1,5419 \%)$ dan terendah pada tahun 2013 sebesar $(1,3179 \%)$. Sedangkan pada perusahaan Sampoerna nilai 
Esty Rohayati, Pengaruh Asimetri Informasi dan Ukuran Perusahaan terhadap Manajemen Laba pada Sub Sektor Industri Rokok yang Terdaftar di Bursa Efek Indonesia Periode 2013-2017

tertinggi pada tahun 2014 sebesar $(2,9286 \%)$ dan nilai terendah pada tahun 2015 sebesar $(1,5632 \%)$. Pada perusahaan Bentoel manajemen laba tertinggi pada tahun 2017 sebesar $(1,7009 \%)$ dan terendah pada tahun 2013 sebesar $(1,5723 \%)$. Dan nilai manajemen laba tertinggi pada perusahaan Wismilak terjadi pada tahun 2017 sebesar $(368.085,6838 \%)$ dan nilai terendah pada tahun 2013 sebesar $(93.567,1055 \%)$. Dengan perkembangan seluruhnya sebesar 74,64\% pada tahun 2013-2014, tahun 2015 perkembangan meningkat sebesar $13,68 \%$ dari tahun sebelumnya, kemudian diikuti meningkatnya perkembangan sebesar $60,84 \%$ dan $23,19 \%$ ditahun 2016 dan 2017.

Selain asimetri informasi, faktor lain yang berhubungan dengan praktik manajemen laba adalah ukuran perusahaan. Menurut Nariastiti dan Ratnadi (2014) serta Muliati (2011) ukuran perusahaan berpengaruh negatif terhadap manajemen laba. Perusahaan dengan ukuran besar biasanya akan lebih berhati-hati dalam menyusun laporan keuangan karena banyak pihak yang memperhatikan serta mengamati pelaporan keuangan yang akan diterbitkan. Sementara itu, penelitian berbeda yang dilakukan oleh Halim, dkk (2005) yang menemukan bahwa ukuran perusahaan berpengaruh positif terhadap manajemen laba. Disisi lain Nasser dan Herlina (2003) menemukan bahwa ukuran perusahaan tidak berpengaruh signifikan terhadap manajemen laba.

\section{METODE}

Untuk memperoleh data imformasi secara refresentatif maka metode pengumpulan data yang digunakan dalam penelitian ini adalah data sekunder, studi ke pustakaan dan populasi dan sampel yang artinya adalah sebagai berikut:

1. Data sekunder

Menurut Sangadji dan Sopiah (2010: 44) data sekunder adalah sumber data penelitian yang diperoleh peneliti secara langsung melalui media perantara (diperoleh dan dicatat oleh pihak lain). Data sekunder biasanya berupa bukti, catatan, atau laporan historis yang telah tersusun dalam arsip (data documenter) yang dipublikasikan maupun tidak dipublikasikan.

2. Studi Kepustakaan (Library Research)

Dimaksudkan untuk memperoleh data kepustakaan dengan cara mempelajari, mengkaji dan menelaah literature-literatur yang berkaitan dengan masalah yang diteliti berupa buku, jurnal maupun makalah yang berkaitan dengan penelitian. Kegunaan penelitian kepustakaan adalah untuk memperoleh dasar-dasar teoritis dalam menganalisis masalah yang diteliti sebagai pedoman untuk melakukan studi dalam penelitian dilapangan.

3. Populasi dan Sampel
Sampel dalam penelitian ini berdasarkan purposive sampling dan pemilihan sampel berdasarkan karakteristik tertentu, dimana karakter sebagai berikut:

a) Terdaftar di Bursa Efek Indonesia (BEI)

b) Perusahaan mempunyai laporan keuangan yang lengkap tahun 2013-2017

c) Melaporkan laporan keuangan tidak berlaba negatif sehingga sampel dipilih

d) Perusahaan menggunakan mata uang Rupiah dalam publikasi laporan keuangan.

Sampel dalam penelitian ini ada 4 perusahaan, dapat dilihat pada tabel 5 dibawah ini:

Tabel 4. Pemilihan Sampel Sub Sektor Industri Rokok Yang Terdaftar di BEI Periode 2013-2017

\begin{tabular}{clc}
\hline No & Proses Pemilihan Sampel & Jumlah \\
\hline 1 & Terdaftar di Bursa Efek Indonesia (BEI) & 4 \\
2 & $\begin{array}{l}\text { Perusahaan mempunyai laporan } \\
\text { keuangan yang lengkap tahun 2013-2017 }\end{array}$ & 4 \\
3 & $\begin{array}{l}\text { Perusahaan menggunakan mata uang } \\
\text { Rupiah dalam publikasi laporan } \\
\text { keuangan. }\end{array}$ & 4 \\
4 & $\begin{array}{l}\text { Perusahaan yang laporan keuangannya } \\
\text { berlaba negatif }\end{array}$ & 1 \\
\hline
\end{tabular}

Sumber : www.idx.co.id

\section{Alat Analisis}

\section{Analisis Regresi Linear Berganda}

Menurut Siregar (2014: 405) regresi liniear berganda merupakan alat yang dapat digunakan untuk melakukan prediksi permintaan di masa yang akan datang, berdasarkan data masa lalu atau untuk mengetahui pengaruh satu atau lebih variabel bebas (independent) terhadap satu variabel tak bebas (dependent). yang diformulasikan sebagai berikut:

$$
\begin{aligned}
& \mathbf{Y}=\mathbf{a}+\mathbf{b}_{1} \mathbf{X}_{1}+\mathbf{b}_{2} \mathbf{X}_{\mathbf{2}}+\mathbf{e} \\
& \text { Keterangan: } \\
& Y=\text { Manajemen Laba } \\
& \mathrm{a}=\text { Konstanta } \\
& \mathrm{b}=\text { koefisien variable } \\
& \mathrm{X}_{1}=\text { Asimetri Informasi } \\
& \mathrm{X}_{2}=\text { Ukuran Perusahaan } \\
& \mathrm{e}=\text { error }
\end{aligned}
$$

\section{Uji Asumsi Klasik}

Fungsi dari uji asumsi klasik dimaksudkan agar model regresi dapat menghasilkan penduga (estimator) yang tidak bias. Model regresi akan menghasilkan penduga yang tidak bias jika memenuhi asumsi klasik, antara lain normalitas data, bebas multikolineritas, bebas autokorelasi dan bebas heterokedasitas.

a. Uji normalitas menurut Priyatno (2009: 56) syarat dalam analisis parametrik, yaitu distribusi data harus normal dan bertujuan untuk menguji apakah model regresi variabel dapenden, variabel independen atau 
keduanya mempunyai distribusi normal atau tidak. Model regresi yang baik adalah memiliki distribusi data normal atau mendekati nol. Menurut Ghozali (2005: 76) uji normalitas dapat dideteksi dengan melihat penyebaran data (titik) pada sumbu diagonal dari grafik. Adapun pengambilan keputusan dalam uji normalitas adalah :

1) Jika data menyebar disekitar garis diagonal dan mengikuti arah garis diagonal, maka model regresi memenuhui asumsi normalitas.

2) Jika data menyebar jauh dari garis diagonal dan tidak mengikuti arah garis diagonal maka model regresi tidak memenuhi asumsi normalitas.

b. Uji multikolinearitas menurut Priyatno (2009: 59) adalah keadaan dimana antara dua variabel independen atau lebih pada model regresi terjadi hubungan linier yang sempurna atau mendekati sempurna. Model regresi yang baik mensyaratkan tidak adanya masalah multikolinearitas. Bertujuan untuk mengetahui ada atau tidaknya hubungan (korelasi) yang signifikan antar variabel bebas. Jika terdapat hubungan yang cukup tinggi (signifikan), berarti ada aspek yang sama diukur pada variabel bebas. Hal ini tidak layak digunakan untuk menentukan kontribusi secara bersama-sama bebas terhadap variabel terikat. Uji multikolinearitas dengan SPSS dilakukan dengan uji regresi, dengan patokan nilai VIF (Variance Inflated Factors) dan koefisien korelasi antar variabel bebas. Kriteria yang digunakan adalah:

1) Jika nilai VIF di sekitar angka 1 atau memiliki tolerance mendekati 1, maka dikatakan tidak terdapat masalah multikolinearitas dalam model regresi.

2) Jika koefisien korelasi antarvariabel bebas kurang dari 0,5 , maka tidak terdapat masalah multikolinearitas.

c. Uji Heteroskedastisitas menurut Priyatno (2009: 60) adalah keadaan dimana terjadinya ketidaksamaan varian dari residual pada model regresi. Bertujuan untuk menguji apakah dalam model regresi terjadi ketidaksamaan varians dari satu pengamatan ke pengamatan lain. Jika varians tersebut tetap maka disebut homoskedastisitas, jika berbeda disebut heteroskedastisitas. Model regresi yang baik adalah yang tidak terjadi heteroskedastisitas.

Heteroskedastisitas terjadi dalam regresi apabila varians error untuk beberapa nilai $X$ tidak konstan atau berubah-ubah. Pendeteksian konstan atau tidaknya varians error konstan dapat dilakukan dengan menggambar grafik. Apabila garis yang membatasi sebaran titik-titik relatif paralel maka varians error dikatakan konstan. (Sumanto, 2014: 169). Deteksi heteroskedastisitas dapat dilakukan dengan metode scatter plot dengan memplotkan nilai ZPRED (nilai prediksi) dengan SRESID (nilai residualnya). Model yang baik didapatkan jika tidak terdapat pola tertentu pada grafik, seperti mengumpul di tengah, menyempit kemudian melebar atau sebaliknya melebar kemudian menyempit.

d. Uji autokorelasi bertujuan untuk menguji apakah model regresi linier ada korelasi antara kesalahan pengganggu pada periode $\mathrm{t}$ dengan kesalahan pengganggu pada period eke t-1 (sebelumnya). Jika terjadi korelasi, maka ada masalah autokorelasi. Autokorelasi muncul karena observasi yang berurutan sepanjang waktu berkaitan satu dengan yang lain. Masalah ini timbul karena residual (kesalahan pengganggu) tidak bebas dari satu observasi ke observasi lainnya, biasanya di jumpai pada deret waktu (time series). Konsekuensi adanya autokorelasi dalam model regresi adalah variancesampel tidak dapat menggambarkan variance populasinya sehingga model regresi yang dihasilkan tidak dapat digunakan untuk menaksir nilai variable dependen ada nilai independen tertentu (Ghozali, 2015: 59). Ghozali menyatakan bahwa untuk mengetahui ada tidaknya masalah autokorelasi dengan uji Durbi Watson dengan kriteria sebagai berikut.

1) $0<\mathrm{d}<\mathrm{dl}$, berarti tidak ada autokorelasi positif dan keputusan ditolak.

2) dl $\leq \mathrm{d} \leq \mathrm{du}$, berarti tidak ada autokorelasi positif dan keputusan no decision.

3) $4-\mathrm{dl}<\mathrm{d}<4$, berarti tidak ada autokorelasi negatif dan keputusan ditolak.

4) $4-\mathrm{dl} \leq \mathrm{d} \leq 4-\mathrm{dl}$, berarti tidak ada autokorelasi negatif dan keputusan no decision.

5) $\mathrm{du}<\mathrm{d}<4-\mathrm{du}$, berarti tidak ada autokorelasi positif atau negatif dan keputusannya di tolak.

\section{Uji Statistik F (F-test)}

Menurut Ghozali (2005: 43) uji F digunakan untuk mengukur ketepatan fungsi regresi sampel dalam menaksir nilai aktual. Uji $\mathrm{F}$ ini dapat diukur dengan melihat statistik $\mathrm{F}$ dan $\mathrm{F}$ tabel. Digunakan untuk menguji keberartian pengaruh dari seluruh variabel independen secara bersama-sama terhadap variabel dependen. Hipotesis ini dirumuskan sebagai berikut:

$\mathrm{H}_{1}: \mathrm{b}_{1}, \mathrm{~b}_{2} \neq 0$

Artinya terdapat pengaruh yang signifikan secara bersama-sama dari variabel independen $\left(\mathrm{X}_{1}\right.$ dan $\left.\mathrm{X}_{2}\right)$ terhadap variabel dependen (Y). Pengambilan keputusan sebagai berikut:

1) Jika probabilitas (nilai Sig.) $<0,05$ atau $F_{\text {hitung }}>F_{\text {tabel }}$ maka $\mathrm{H}_{0}$ diterima dan $\mathrm{H}_{\mathrm{a}}$ ditolak.

2) Jika probabilitas (nilai Sig.) $>0,05$ atau $F_{\text {hitung }}<F_{\text {tabel }}$ maka $\mathrm{H}_{0}$ ditolak dan $\mathrm{H}_{\mathrm{a}}$ diterima.

Adapun hipotesisnya sebagai berikut:

3) $\mathrm{H}_{0}=$ tidak ada pengaruh signifikan dari variable independent secara simultan (bersama-sama) antara variabel arus kas, current ratio dan cash ratio 
(variabel independen) terhadap variabel laba bersih (variabel dependen).

4) $\mathrm{H}_{1}=$ terdapat pengaruh signifikan dari variabel independent secara simultan (bersama-sama) antara variabel arus kas, current ratio dan cash ratio (variabel independen) terhadap variable laba bersih (variabel dependen).

\section{Uji Statistik $t$ (t-test)}

Menurut Siregar (2014: 194) Uji t (t-test) digunakan untuk mengetahui kebenaran pernyataan atau dugaan yang dihipotesiskan oleh si peneliti. Derajat signifikansi yang digunakan adalah 0,05. Hal ini dilakukan untuk menguji koefisien regresi secara parsial dari variabel independennya. Adapun hipotesis dilakukan sebagai berikut:

$\mathrm{H}_{1}: \mathrm{b}_{1} \neq 0$

Artinya terdapat pengaruh yag signifikan dari variabel independen $\left(\mathrm{X}_{1}\right.$ dan $\left.\mathrm{X}_{2}\right)$ terhadap variabel dependen (Y). Pengambilan keputusannya sebagai berikut:

1) Jika probabilitas (nilai Sig.) $<0,05$ atau $t_{\text {hitung }}>t_{\text {tabel }}$ maka $\mathrm{H}_{0}$ ditolak dan $\mathrm{H}_{\mathrm{a}}$ diterima.

2) Jika probabilitas (nilai Sig.) $>0,05$ atau $t_{\text {hitung }}<t_{\text {tabel }}$ maka $\mathrm{H}_{0}$ diterima dan $\mathrm{H}_{\mathrm{a}}$ ditolak.

Adapun hipotesisnya sebagai berikut:

1) $\mathrm{H}_{0}=$ tidak ada pengaruh signifikan secara parsial antara variabel arus kas, current ratio dan cash ratio (variabel independen) terhadap variabel laba bersih (variabel dependen).

2) $\mathrm{H}_{1}=$ ada pengaruh signifikan secara parsial antara variabel arus kas, current ratio dan cash ratio (variabel independen) terhadap variabel laba bersih (variabel dependen).

\section{Uji Koefisien Determinasi $\left(R^{2}\right)$}

Menurut Siregar (2014: 338), koefisien determinasi adalah angka yang menyatakan atau digunakan untuk mengetahui kontribusi atau sumbangan yang diberikan oleh sebuah variabel bebas $(\mathrm{X})$ terhadap variabel terikat (Y). Secara sederhana koefisien determinasi dihitung dengan mengkuadratkan Koefisien Korelasi (R). Sebagai contoh, jika nilai R adalah sebesar 0,80 maka koefisien determinasi ( $\mathrm{R}$ square) adalah sebesar $0,80 \times 0,80=0,64$. Berarti kemampuan variabel bebas dalam menjelaskan varians dari variabel terikatnya adalah sebesar $64,0 \%$. Berarti terdapat 36\% (100\%-64\%) varians variabel terikat yang dijelaskan oleh faktor lain.

\section{HASIL DAN PEMBAHASAN Regresi Linier Berganda}

Digunakan untuk melakukan prediksi permintaan di masa yang akan datang, berdasarkan data masa lalu atau untuk mengetahui pengaruh satu atau lebih variabel bebas (independent) terhadap satu variabel tak bebas (dependent).

Tabel 5. Hasil Persamaan Regresi Linier Berganda

Coefficients $^{\mathrm{a}}$

\begin{tabular}{|c|c|c|c|c|c|c|}
\hline \multicolumn{2}{|c|}{ Model } & \multicolumn{2}{|c|}{\begin{tabular}{cc}
\multicolumn{3}{c}{ Unstandardized Coefficients } \\
B & Std. Error \\
\end{tabular}} & $\begin{array}{c}\text { Standardized Coefficients } \\
\text { Beta }\end{array}$ & $\mathrm{t}$ & Sig. \\
\hline 1 & (Constant) & .096 & .135 & & .710 & .607 \\
\hline & Zscore(Log_X1) & -.647 & 261 & -.470 & -2.475 & 244 \\
\hline & Zscore(Log_X2) & -1.050 & 146 & -1.364 & -7.190 & .088 \\
\hline
\end{tabular}

a. Dependent Variable: Zscore(Log_Y)

Dari tabel 5 di atas dapat diketahui bahwa persamaan regresi linier berganda adalah sebagai berikut:

$\mathrm{Y}=0,096-0,647 \mathrm{X}_{1}-1,050 \mathrm{X}_{2}+\mathrm{e}$

Keterangan:

a (konstanta) $=0,096$

koefisien $X_{1}=-0,647 X_{1}$

koefisien $\mathrm{X}_{2}=-1,050 \mathrm{X}_{2}$

Berdasarkan persamaan regresi berganda dapat diartikan sebagai berikut:

a. Nilai konstanta hasil regresi data dari tahun 2013 sampai dengan tahun 2017 adalah sebesar 0,096, artinya jika asimetri informasi dan ukuran perusahaan distribusi nilainya 0 (nol), maka manajemen laba nilainya 0,096 . b. Koefisien $X_{1}$ sebesar $-0,647$, artinya jika variabel ukuran perusahaan nilainya tetap dan asimetri informasi ditingkatkan sebesar Rp. 1,- maka manajemen laba akan meningkat sebesar Rp. 0,647,-.

c. Koefisien $X_{2}$ sebesar $-1,050$, artinya jika variabel asimetri informasi dan ukuran perusahaan ditingkatkan sebesar Rp. 1,- maka manajemen laba akan meningkat sebesar Rp. -1,050,-.

\section{Uji Asumsi Klasik}

a. Uji Normalitas

Bertujuan untuk menguji apakah model regresi variabel dapenden, variabel independen atau keduanya mempunyai distribusi normal atau tidak. Model regresi yang baik adalah memiliki distribusi data normal atau mendekati nol. 


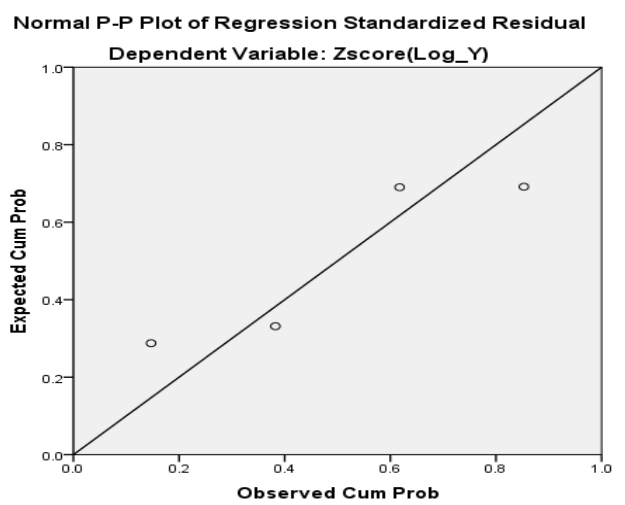

Gambar 1. Hasil Uji Normalitas Data

Kriteria pengambilan keputusan yaitu sebagai berikut

1) Jika data menyebar di sekitar garis diagonal dan mengikuti arah diagonal, maka model regresi memenuhi asumsi normalitas

2) Jika data menyebar jauh dari garis diagonal atau tidak mengikuti arah diagonal, maka model regresi tidak memenuhi asumsi normalitas.

Dari gambar 1 diatas dapat dilihat bahwa data menyebar di sekitar garis diagonal dan mengikuti arah garis diagonal, maka data terdistribusi dengan normal dan model regresi telah memenuhi asumsi normalitas.

b. Uji Multikolineritas

Dimaksudkan untuk mengetahui ada atau tidaknya hubungan (korelasi) yang signifikan antar variabel bebas. Jika terdapat hubungan yang cukup tinggi (signifikan), berarti ada aspek yang sama diukur pada variabel bebas.

Tabel 6. Hasil uji multikolinearitas Coefficients $^{\mathrm{a}}$

\begin{tabular}{llrr}
\hline \multirow{2}{*}{ Model } & & \multicolumn{2}{c}{ Collinearity Statistics } \\
Tolerance & VIF \\
\hline 1 & (Constant) & & \\
& Zscore(Log_X1) &, 274 & 3,652 \\
& Zscore(Log_X2) &, 274 & 3,652 \\
\hline
\end{tabular}

a Dependent Variable: Zscore(Log_Y)
Dari tabel 6 diatas menjelaskan bahwa data yang ada terjadi gejala multikolinearitas antara masing-masing variabel independen (bebas) kurang dari 0,5 maka tidak terdapat masalah multikolinearitas.

c. Uji Heteroskedastisitas

Bertujuan untuk menguji apakah dalam model regresi terjadi ketidaksamaan varians dari satu pengamatan ke pengamatan lain. Jika varians tersebut tetap maka disebut homoskedastisitas, jika berbeda disebut heteroskedastisitas. Adapun uji heteroskedastisitas adalah sebagai berikut:

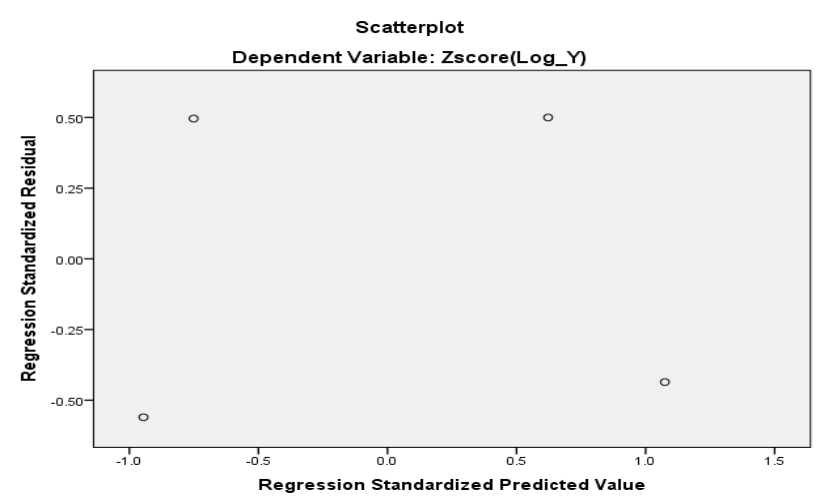

Gambar 2. Hasil Uji Heteroskedastisitas

Berdasarkan gambar 2 diatas terlihat bahwa titik tidak berbentuk pola yang teratur dan tersebar diatas dan dibawah titik -1. Selain itu titik-titik tidak mengumpul disatu tempat saja, dengan demikian dalam model regresi ini terjadi hemoskedastisitas atau tidak terjadi heteroskedastisitas. Karena tidak terjadi heteroskedastisitas maka model regresi ini bisa digunakan analisis regresi berganda.

d. Uji Autokorelasi

Uji autokorelasi bertujuan untuk menguji apakah dalam model regresi linier terdapat korelasi antara kesalahan pengganggu pada periode $t$ dengan kesalahan pada periode sebelumnya (t-1). Jika terjadi korelasi, maka dinamakan ada problem autokorelasi. Model regresi yang baik adalah yang bebas dari autokorelasi.

Hasil 7. Uji Autokorelasi

Model Summary ${ }^{\mathrm{b}}$

\begin{tabular}{|c|c|c|c|c|c|}
\hline Model & $\mathrm{R}$ & R Square & Adjusted R Square & Std. Error of the Estimate & Durbin-Watson \\
\hline 1 & $995^{\mathrm{a}}$ & 990 & 970 & 18697443 & 2,007 \\
\hline
\end{tabular}

a. Predictors: (Constant), Zscore(Log_X2), Zscore(Log_X1)

b. Dependent Variable: Zscore(Log_Y)

Dari tabel 7 diatas menyatakan nilai DurbinWatson untuk variabel dependen adalah 2,007. Nilai dl dan du dapat dilihat pada tabel Durbin-Watson pada signifikasi $0,05, \mathrm{n}=20$ dan $\mathrm{k}=2$ ( $\mathrm{n}$ adalah jumlah data dan $\mathrm{k}$ adalah jumlah variabel independen). Di dapat $\mathrm{dl}=$ 1,100 dan $\mathrm{du}=1,537$.
Pengambilan keputusan jika :

1) $\mathrm{du}<\mathrm{d}<4$-du maka $\mathrm{H}_{0}$ diterima (tidak terjadi autokorelasi)

2) $\mathrm{d}<\mathrm{dl}$ atau $\mathrm{d}>$ 4-dl maka $\mathrm{H}_{0}$ ditolak (terjadi autokorelasi) 
Esty Rohayati, Pengaruh Asimetri Informasi dan Ukuran Perusahaan terhadap Manajemen Laba pada Sub Sektor Industri Rokok yang Terdaftar di Bursa Efek Indonesia Periode 2013-2017

3) dl $<$ d $<$ dl atau 4-du $<$ d $<$ 4-dl maka tidak ada kesimpulan.

Dari hasil uji autokorelasi yang ditunjukkan oleh tabel 4.7 diketahui nilai d (Durbin-Watson) sebesar 2,007 terletak pada daerah du < d <4-du $(1,100<2,007<$ 1,100), maka dapat disimpulkan tidak adanya autokorelasi positif dan keputusannya adalah no decision atau tidak dapat disimpulkan/diputskan.

\section{Uji Simultan (F-Test)}

Uji $F$ ini dapat diukur dengan melihat statistik $F$ dan $F$ tabel. Digunakan untuk menguji keberartian pengaruh dari seluruh variabel independen secara bersama-sama terhadap variabel dependen.

Tabel 8. Hasil Uji F

ANOVA $^{\mathrm{a}}$

\begin{tabular}{|c|c|c|c|c|c|c|}
\hline Model & & Sum of Squares & $\mathrm{df}$ & Mean Square & $\mathrm{F}$ & Sig. \\
\hline \multirow{3}{*}{1} & Regression & 3.511 & 2 & 1.755 & 50.212 & $.099^{\mathrm{b}}$ \\
\hline & Residual & .035 & 1 & .035 & & \\
\hline & Total & 3.546 & 3 & & & \\
\hline
\end{tabular}

a. Dependent Variable: Zscore(Log_Y)

b. Predictors: (Constant), Zscore(Log_X2), Zscore(Log_X1)

Dari table 8 diatas dapat dilihat bahwa $F_{\text {hitung }}$ $(50,212)$ lebih besar dari pada $F_{\text {tabel }}(3,5915)$ maka dengan tingkat kekeliruan 5\% $(\alpha=0,05)$, maka $\mathrm{H}_{0}$ ditolak dan $\mathrm{H}_{1}$ diterima. Artinya dengan tingkat kepercayaan 95\% dapat disimpulkan bahwa asimteri informasi dan ukuran perusahaan secara simultan berpengaruh signifikan terhadap manajemen laba pada sub sektor industri rokok yang terdaftar di BEI periode 2013-2017.

\section{Uji Parsial (t-test)}

Digunakan untuk mengetahui kebenaran pernyataan atau dugaan yang dihipotesiskan oleh si peneliti.

Tabel 9. Hasil Uji t

Coefficients $^{\mathrm{a}}$

\begin{tabular}{|c|c|c|c|c|c|c|}
\hline \multirow{2}{*}{\multicolumn{2}{|c|}{ Model }} & \multicolumn{2}{|c|}{ Unstandardized Coefficients } & \multirow{2}{*}{$\frac{\text { Standardized Coefficients }}{\text { Beta }}$} & \multirow[t]{2}{*}{$\mathrm{t}$} & \multirow[t]{2}{*}{ Sig. } \\
\hline & & $\mathrm{B}$ & Std. Error & & & \\
\hline \multirow[t]{3}{*}{1} & (Constant) & .096 & .135 & & .710 & .607 \\
\hline & Zscore(Log_X1) & -.647 & 261 & -.470 & -2.475 & .244 \\
\hline & Zscore(Log_X2) & -1.050 & .146 & -1.364 & -7.190 & .088 \\
\hline
\end{tabular}

a. Dependent Variable: Zscore(Log_Y)

Berdasarkan hasil uji t pada tabel 9 diatas, maka akan dijelaskan pengaruh variabel independent terhadap variabel dependent secara parsial sebagai berikut :

1. Asimetri Informasi

Variabel asimetri informasi sebesar 2,475 dengan nilai $\mathrm{t}_{\text {tabel }} 2,120$ atau $2,475>2,120$, jadi $\mathrm{t}_{\text {hitung }}>\mathrm{t}_{\mathrm{tabel}}$, maka $\mathrm{H}_{0}$ ditolak dan $\mathrm{H}_{\mathrm{a}}$ diterima. Dari hasil uji $\mathrm{t}$ dapat disimpulkan, variabel asimetri informasi berpengaruh signifikan terhadap manajemen laba.

2. Ukuran Perusahaan
Variabel ukuran perusahaan $t_{\text {hitung }}$ sebesar 7,190 dengan nilai $t_{\text {tabel }} 2,120$ atau $7,190>2,120$, jadi thitung $>\mathrm{t}_{\text {tabel, }}$ maka $\mathrm{H}_{0}$ ditolak dan $\mathrm{H}_{\mathrm{a}}$ diterima. Dari hasil uji $\mathrm{t}$ dapat disimpulkan, variabel ukuran perusahaan berpengaruh signifikan terhadap manajemen laba

\section{Koefisien Determinasi $\left(R^{2}\right)$}

Koefisien determinasi adalah angka yang menyatakan atau digunakan untuk mengetahui kontribusi atau sumbangan yang diberikan oleh sebuah variabel bebas $(\mathrm{X})$ terhadap variabel terikat $(\mathrm{Y})$.

Tabel 10. Hasil Koefisien Determinasi $\left(\boldsymbol{R}^{2}\right)$ Model Summary ${ }^{\mathrm{b}}$

\begin{tabular}{lrrrrr}
\hline Model & R & R Square & Adjusted R Square & Std. Error of the Estimate & Durbin-Watson \\
\hline 1 &, $995^{\mathrm{a}}$ &, 990 &, 970 &, 18697443 & 2,007 \\
\hline
\end{tabular}

a. Predictors: (Constant), Zscore(Log_X2), Zscore(Log_X1)

b. Dependent Variable: Zscore $\left(\log _{-} \mathrm{Y}\right)$

Pada tabel 10 di atas dapat dilihat bahwa besarnya koefisien determinasi atau (R Square) dari hasil regresi kedua variabel independent (Asimetri Informasi dan Ukuran Perusahaan) terhadap Manajemen Laba pada 4 
Esty Rohayati, Pengaruh Asimetri Informasi dan Ukuran Perusahaan terhadap Manajemen Laba pada Sub Sektor Industri Rokok yang Terdaftar di Bursa Efek Indonesia Periode 2013-2017

(empat) perusahaan sub sektor industri rokok yang terdaftar di BEI sebesar 99,0\% jadi berdasarkan hasil penelitian diketahui besarnya pengaruh variabel Asimetri Informasi dan Ukuran Perusahaan terhadap Manajemen Laba pada 4 (empat) perusahaan sub sektor industri rokok yang terdaftar di BEI adalah 99,0\% (100-99,0) dan sisanya $1,0 \%$ dipengaruhi faktor lain yang tidak diteliti dalam penelitian.

\section{SIMPULAN}

Berdasarkan hasil penelitian dari pembahasan maka dapat disimpulkan sebagai berikut:

1. Berdasarkan hasil dari uji $F$, maka nilai $F$ sebesar 50,212 karena $F_{\text {hitung }}(50,212)$ lebih besar dari pada $F_{\text {tabel }}(3,5915)$ maka dengan tingkat kekeliruan 5\% $(\alpha=0,05)$, maka $\mathrm{H}_{0}$ ditolak dan $\mathrm{H}_{1}$ diterima. Artinya dengan tingkat kepercayaan 95\% dapat disimpulkan bahwa (asimetri informasi dan ukuran perusahaan) secara simultan berpengaruh signifikan terhadap manajemen laba.

2. Berdasarkan uji t parsial, yaitu :

a. Variabel asimetri informasi sebesar 2,475 dengan nilai $t_{\text {tabel }} 2,120$ atau $2,475>2,120$, jadi $t_{\text {hitung }}>$ $\mathrm{t}_{\text {tabel, }}$ maka $\mathrm{H}_{0}$ ditolak dan $\mathrm{H}_{\mathrm{a}}$ diterima. Dari hasil uji $\mathrm{t}$ dapat disimpulkan, variabel asimetri informasi berpengaruh signifikan terhadap manajemen laba.

b. Variabel ukuran perusahaan $t_{\text {hitung }}$ sebesar 7,190 dengan nilai $t_{\text {tabel }} 2,120$ atau $7,190>2,120$, jadi $t_{\text {hitung }}>\mathrm{t}_{\mathrm{tabel}}$, maka $\mathrm{H}_{0}$ ditolak dan $\mathrm{H}_{\mathrm{a}}$ diterima. Dari hasil uji t dapat disimpulkan, variabel ukuran perusahaan berpengaruh signifikan terhadap manajemen laba.

\section{DAFTAR PUSTAKA}

Annamaria Rinesti. 2016. Hubungan Asimetri Informasi dan Ukuran Perusahaan Dengan Praktik Manajemen Laba (Studi Empiris Pada Perusahaan Maunufaktur Yang Terdaftar Di BEI 2012-2014). Skripsi Fakultas Ekonomi Universitas Sanata Dharma. Yogyakarta

Asosiasi Kartu Kredit Indonesia (AKKI), dalam Lakan Aureole, ibid

Badruzaman, Nunung. 2010. Earning Management. Modul

Chtourou SM, Jean Bedard dan Luis Courteau. 2001. Coorporate Governance and Earning Management. Working Paper

Desmiyawati, Nasrizal dan Yessy. 2009. Pengaruh Asimetri Informasi dan Ukuran Perusahaan Terhadap Praktik Manajemen laba Pada Perusahaan Manufaktur Yang Terdaftar Di BEI. Pekbis Jurnal Vol.1 No.3

Dewi, Monica. 2007. Pengaruh Leverage Perusahaan, Ukuran Perusahaan dan Corporate Governance Terhadap Manajemen Laba (Studi Kasus
Perusahaan Manufaktur Yang Listing Di BEJ). Skripsi Universitas Brawijaya Malang

Fahmi, Irham. 2013. Analisis Laporan Keuangan. Alfabeta : Bandung

Ghozali, Imam. 2005. Aplikasi Analisis Multifariate dengan Program SPSS. Edisi Ketiga. Badan Penerbit UNDIP : Semarang

Ghozali, Imam dan Anis Chairi. 2007. Teori Akuntansi Edisi Ketiga. Badan Penerbit Universitas Diponogoro: Semarang

Hartono, Jogiyanto dan Riyanto, Bambang. 1997. The Effect of Asimetrical Information and Risk Attitude on Insentive Schemes: A Contigency Approach. Jurnal Ekonomi dan Bisnis Indonesia. Vol. 12. No.1: 1-12

Halim. J, Meiden. C dan Tobing. 2005. "Pengaruh Manajemen Laba Pada Tingkat Pengungkapan Laporan Keuangan Pada Perusahaan Manufaktur Yang Termasuk Dalam Indeks LQ-45". Simposium Nasional Akuntansi VIII

Husnan, Suad. 2012. Dasar-dasar Manajemen Keuangan. BPFE : Yogyakarta

Hery. 2015. Analisis Laporan Keuangan Pendekatan Rasio Keuangan. CABS (Center for Academic Publishing Service) : Yogyakarta.

Harmono. 2011. Manajemen Keuangan. PT Bumi Aksara: Jakarta

Halim, J, Meiden, C dan Tobing. 2005. Pengaruh Manajemen Laba Pada Tingkat Pengungkapan Laporan Keuagan Pada Perusahaan Manufaktur Yang Termasuk Dalam Indeks LQ-45 Solo Simposium Nasional Akuntansi VIII

Indrawan, Rully dan Yaniawati, Poppy, R. 2014. Metodologi Penelitian Kuantitatif, Kualitatif dan Campuran untuk Manjemen, Pembangunan dan Pendidikan. PT Refika Aditama : Bandung

Ikatan Akuntansi Indonesia. 2007. Standar Akuntansi Keuangan. Salemba Empat: Jakarta

Ikatan Akuntansi Indonesia (IAI). 2009. Standar Akuntansi Keuangan Revisi. Penerbit Salemba Empat: Jakarta

Kasmir. 2014. Analisis Laporan Keuangan. PT Raja Grafindo : Jakarta.

Komalasari, Puput T. 2001. Asimetri Informasi Dan Cost of Equity Capital Simposium Nasional Akuntansi III

Meutia, Inten. 2004. Pengaruh Independensi Auditor Terhadap Manajemen Laba Untuk KAP Big 5 dan Non Big 5. Jurnal Riset Akuntansi Indonesia. Vol. 7 No. 3

Muliati, Ni Ketut. 2011. Pengaruh Asimetri Informasi dan Ukuran Perusahaan Pada Praktik Manajemen Laba di Perusahaan Perbankan Yang Terdaftar di BEI. Tesis Program Studi Akuntansi Program Pasca Sarjana Universitas Udayana Denpasar 
Esty Rohayati, Pengaruh Asimetri Informasi dan Ukuran Perusahaan terhadap Manajemen Laba pada Sub Sektor Industri Rokok yang Terdaftar di Bursa Efek Indonesia Periode 2013-2017

Misbahuddin dan Hasan. 2013. Analisis Data Penelitian Dengan Statistik Edisi ke 2. Bumi Aksar0061 : Jakarta

Nadia Dhaneswari dan Retnaningtyas Widuri. 2013. Pengaruh Asimetri Informasi, Ukuran Perusahaan dan Beban Pajak Tangguhan Terhadap Praktik Manajemen Laba di PeruahaanManufaktur yang Terfdaftar di BEI 2010-2012. Jurnal Tax and accounting Vol. 3 No.2 Universitas Kristen Petra. Surabaya

Nasution, Marihot dan Setiawan, Doddy. 2007. Pengaruh Corporate Governance Terhadap Manajemen Laba di Industri Perbankan Simposium Nasional Akuntansi X

Nasser, E.M. dan Herlina. 2003. Pengaruh Size, Profitabilitas dan Leverage Terhadap Perataan Laba Pada Perusahaan Go Publik. Jurnal Ekonomi Vol. 7(3) Hal. 291-305

Nariastiti, Ni Wayan dan Dwi Ratnadi, Ni Made. 2014. Pengaruh Asimetri Informasi, Corporate Governance dan Ukuran Perusahaan pada Manajemen Laba. E- Jurnal Akuntansi Universitas Udayana 9.3

Nuryaman. 2008. Pengaruh Konsentrasi Kepemilikan, Ukuran Perusahaan dan Mekanisme Corporate Governance Terhadap Manajemn Laba Simposium Nasional Akuntansi XI

Priyatno, Duwi. 2009. SPSS Analisis Korelasi, Regresi dan Multivariate. Gava Media: Yogyakarta

Restu Agusti dan Tyas Pramesti. 2008. Pengaruh Asimetri Informasi Ukuran Perusahaan Kepemilikan Manajerial Terhadap Manajemen Laba Perusahaan Manufaktur yang Terdaftar Di BEI Periode 2005-2007. Jurnal Fakultas Ekonomi Jurusan Akuntansi Universitas Riau. Riau

Restuwulan. 2013. Pengaruh Asimetri Informasi dan Ukuran Perusahaan Terhadap Manajemen Laba (penelitian pada perusahaan di sektor industry food and baverages yang terdaftar di BEI tahun 2009-2011. Skripsi Universitas Widyatama. Bandung

Richardson, V. J. 1998. Information Asymetry and Earnings Management: Some Evidence. http/www.ssrn.com

Rahmawati, dkk. 2006. Pengaruh Asimetri Informasi Terhadap Praktik Manajemen Laba Pada Perusahaan Perbankan Publik Yang Terdaftar Di BEI Simposium Nasional Akuntansi IX

Sastradipraja, U. 2010. Analisis dan Penggunan Laporan Keuangan Pada Program Studi Akuntansi Fakultas Ekonomi. Bandung

Sartono, Agus. 2008, "Manajemen Keuangan Teori dan Aplikasi”, Edisi Empat, BPFE; Yogyakarta

Setiawati, L dan Naim. 2000. Manajemen Laba Jurnal Ekonomi dan Bisnis Indonesia. Vol. 15, No. 4 Halaman 424-441
Siaran Pers Badan Pengawas Pasar Modal. Kasus PT. Kimia Farma. 27 Desember 2002

Scott, William R. 2000. Financial Accounting Theory Second Edition. Prentice Hall: USA

Siregar, Syofian. 2014. Statistik Parametrik untuk Penelitian Kuantitatif. PT Bumi Aksara: Jakarta

Simorangkir, O.P. 2004. Pengantar Lembaga Keuangan Bank dan Non Bank. Ghalia Indonesia: Jakarta

Sangadji Etta Mamang dan Sopiah. 2010. Metodologi Penelitian. CV Andi Offset: Yogyakarta

Suryani, Arna, dkk. 2018. Analysis of Opportunistic Behavior of Management to Company Performance. Polish Journal Of management Studies 18 (1), 379-387.

Suryani, Arna. 2017. Koefisien Respon Laba dan Manajemen Laba Studi Konservatisme. Tangga Ilmu: Yogyakarta

Sumanto. 2014. Statistika Terapan. CABS (Center for Academic Publishing Service) : Yogyakarta

Sulistyanto, Sri. 2008. Manajemen Laba Teori dan Model Empiris. Gransindo: Jakarta

Sugiyono. 2004. Statistika Untk Penilaian. Alfabeta: Bandung

Ujiyanto, Arif Muh dan Bambang, Agus. 2007. Mekanisme Corporate Governance, Manajemen Laba Dan Kinerja Keuangan Simposium Nasional Akuntansi X

Utami, W. 2006. Pengaruh Manajemen Laba terhadap Biaya Modal Ekuitas (Studi Pada Perusahaan Publik Sektor Manufaktur). Jurnal Riset Akuntansi Indonesia 9 (2): 178-199

Veronica, S dan Utama, Siddharta. 2005. Pengaruh Struktur Kepemilikan, Ukuran Perusahaan dan Praktik Corporate Governance Terhadap Pengelolaan Laba (Earning Management) Simposium Nasional Akuntansi VIII

Widyaningdiyah. 2004. Analisa Faktor-faktor Yang Mempengaruhi Pilihan Perusahaan Terhadap Akuntansi Konservatif. Dipresentasikan di Simposium Nasional Akuntansi. Denpasar

Yulius, Budi Setiawan. 2017. Hubungan Asimetri dan Ukuran Perusahaan Dengan Manajemen Laba (studi empiris para perusahaan manufaktur yang terdaftar di BEI tahun 2011-2015). Skripsi Universitas Sanata Dharma. Yogyakarta

www.idx.co.id

www.finance.yahoo.com 